\title{
Comparison of Plasma Zinc Levels Among HIV+ and HIV-Subjects Infected with Condyloma Acuminata
}

\author{
Anak Agung Gde Putra Wiraguna1*, Putu Indah Andriani², Made Swastika \\ Adiguna ${ }^{1}$
}

\begin{abstract}
Background: Condyloma acuminata is a type of human papilloma virus (HPV) infection in the anogenital area and often associated with immunosuppressive conditions, such as human immunodeficiency virus (HIV). Low plasma zinc levels could cause alteration of cellular immunity, leading to reduction of interleukin-2 (IL-2) and interferon- $\gamma$ (IFN- $\gamma$ ), cytokines required for inhibition of HPV replication. Moreover, low plasma zinc levels could cause disruption of apoptotic regulation, results in the unimpeded proliferation of epithelial cells infected with HPV. This study aimed to compare the mean plasma zinc levels in condyloma acuminata patients with HIV and without HIV infection. Methods: This study used a cross-sectional method, involving 27 condyloma acuminata patients without HIV infection and 18 patients with HIV infection, who agreed to enroll and signed the informed consent. This study was conducted in the dermatology and venereology outpatient clinic in Sanglah Hospital and Kerti Praja Foundation, Denpasar. Bivariate analysis of the characteristics, age, sex orientation, location of lesion, clinical form of lesion, type of cases, duration of condyloma acuminata, age of the first sexual contact, comorbidity, treatment history, and mean plasma zinc level of condyloma acuminata patients with HIV and without HIV infection. The CD4+ cell count and history of ARV treatment were also obtained form patients with HIV infection. Results: A total of 45 subjects were diagnosed with condyloma acuminata, consisted of 27 subjects with condyloma acuminata without HIV infection and 18 subjects with HIV infection, showing average age of $32.04 \pm 10.414$. Mean plasma zinc levels in condyloma acuminata patients with HIV infection was significantly lower than subjects without HIV infection, and the difference in mean plasma zinc levels was $7.31 \mu \mathrm{g} / \mathrm{dL}(95 \%$ CI $2.25-12.37, \mathrm{p}<0.05)$. Conclusions: The mean plasma zinc levels in condyloma acuminata patients with HIV was significantly lower than those of without HIV infection.
\end{abstract}

Keywords: Condyloma acuminata- HPV- HIV- plasma zinc levels

Asian Pac J Cancer Prev, 20 (3), 943-949

\section{Introduction}

Human papilloma virus (HPV) is a DNA virus that can infect skin and mucous tissue, especially in squamous epithelial cells. HPV can cause benign lesions such as condyloma acuminata or malignant lesions that are often subclinical (Burk et al., 2011; Gredenberg et al., 2004). The prevalence of HPV infection in the United States was $15 \%$ of the general population, whereas in Sanglah Hospital Denpasar, the reported cases were 231 cases (4.27\%) over 2 years, between 2014-2016 (Paflefsky et al., 2009; Puspawati et al., 2018).

Coinfection of condyloma acuminata is often found among those living with HIV. The prevalence of condyloma acuminata with HIV infection in the dermatology and venereology outpatient clinic Sanglah Hospital in 2015 was 31 cases, in 2016 was 28 cases, and in 2017 was 27 cases (Puspawati et al., 2018). In patients with HIV infection there was a decrease in the number of Langerhans cells, CD4+ cells, macrophages, neutrophils, and natural killer cells (NK), thus caused changes in local immunity that modulate HPV infection in tissues (Levi et al., 2005; Kobayashi et al., 2008). Chaturvedi et al., (2009) showed that the incidence of HPV was found to be higher in patients with lower CD4+ cell counts, and the HPV virus were frequently detected among immunosuppressive conditions. Circulating memory $\mathrm{T}$ cells against specific HPV also decreases in conditions of HIV infection.

Zinc is one type of the minerals that is necessary for the function of immune system. Low plasma zinc levels can cause reduced immunity as zinc is an indispensable element for the formation of thymulin hormone, thus low plasma zinc levels can cause thymus atrophy and reduction in the number of thymocytes. This process will result in the decrease of T-helper 1 (Th1) cells maturation, inhibiting the production of IL-2 and IFN- $\gamma$, which play a role in 
inhibiting HPV replication. Low plasma zinc levels also causes the dysregulation of cell apoptosis, leading to the unimpeded proliferation of epithelial cells infected with HPV (Prasad, 2009).

The aim of this study was to determine that lower plasma zinc levels in condyloma acuminata patients with HIV was lower than patients without HIV infection.

\section{Materials and Methods}

The study involved 45 patients with anogenital condyloma acuminata, consisted of 27 patients without HIV infection and 18 patients with HIV infection. The inclusion criteria were subjects over the age of 18 , Indonesian citizens, men and women diagnosed with condyloma acuminata and who had engaged in active sexual activity, were willing to be examined, to have venous blood taken, and able to provide informed consent. Exclusion criteria were pregnancy, breastfeeding, use of hormonal contraceptives, chronic systemic diseases such as chronic kidney failure, coronary heart disease, rheumatoid arthritis, systemic lupus erythematosus, diabetes mellitus, bronchial asthma, malignancy, liver cirrhosis, psoriasis, atopic dermatitis, enteropathic acrodermatitis, chronic diarrhea, smokers, alcohol drinkers, systemic anti-inflammatory treatment, antibiotics use (quinolones, tetracycine), diuretic treatment (Thiazide, Loop Diuretics, Disulfirams), and use of zinc supplements in the last 4 weeks. Samples were recruited by consecutive sampling, from May to August 2018, at the dermatology and venereology outpatient clinic Sanglah Hospital and Kerti Praja Foundation Denpasar.

The clinical diagnosis of condyloma acuminata is established based on clinical examination accompanied by acetowhite examination using $5 \%$ acetic acid left for 2 minutes on the lesion. Assessment of condyloma acuminata severity was based on the number of lesions and the area involved by the lesions. Clinical severity judgement were made on each sites, from perianal skin, intraanal and genitalia mucous membrane.

Plasma zinc levels were measured using a spectrophotometer using the Inductively Coupled Plasma Mass Spectrometry (ICP-MS). $5 \mathrm{ml}$ of venous blood was drawn for examination of plasma zinc levels. Plasma zinc levels are expressed in units of $\mu \mathrm{g} / \mathrm{dL}$. Examination of CD4 + cell counts used a flow cytometry to obtain CD4 + cell counts per mm3. HIV was tested using the Ongkoprob intec rapid test with ST Biolin reagents (USA).

\section{Statistic analysis}

Bivariate analysis in this study was aimed to evaluate the relationship between various variable characteristics in each group of condyloma acuminata with or without HIV infection. The characteristics of the variables described in the form of frequency and percentage, compared using the chi-square test. Values of severity in each location of the genitalia, perianal, and mucosal surface were presented in the form of frequencies and percentages. In the condyloma acuminata group with HIV infection, additional data were obtained in the form of CD4 + cell count and history of consumption of ARV treatment.
Differences in the mean plasma zinc levels in the condyloma acuminata group with HIV infection and without HIV infection were analyzed by unpaired T test because plasma zinc levels in both groups had normal data distribution. Test the normality of data using Shapiro-Wilk test. Statistical analysis in this study used SPSS 23.0.

\section{Results}

The study sample was divided into two groups, namely group I with 27 subjects with condyloma acuminata without HIV infection and group II with 18 subjects with condyloma acuminata with HIV infection. Variable characteristics in each group can be seen in Table 1 .

A total of 45 subjects were diagnosed with condyloma acuminata, with a mean age of $32.04 \pm 10.414$. The bivariate analysis showed that data on sex, sexual orientation, and location of lesions was significantly different between the two groups of condyloma acuminata with HIV infection and without HIV infection with $\mathrm{p}$ $<0.05$.

The values of the severity of the genitalia, perianal skin, and intraanal mucosa in each of these groups can be seen in Table 2. The severity of condyloma acuminata was given values of 1 to 5 at each location in the genital, perianal, and intraanal mucosa. The severity in the genital area with a value of 5 was found in 5 people $(8.3 \%)$ subjects with condyloma acuminata without HIV infection and 1 person $(1.7 \%)$ in subjects with condyloma acuminata with HIV infection. Perianal severity with a score of 5 was found in 2 people (3.3\%) subjects with condyloma acuminata with HIV infection. Intraanal mucosal severity with a value of 5 was found in 4 people $(6.7 \%)$ subjects with condyloma acuminata with HIV infection.

In condyloma acuminata subjects with HIV infection CD4 + cell count and a history of ARV treatment data were obtained. All subjects with condyloma acuminata with HIV infection in this study had received ARV treatment. In anogenital condyloma acuminata subjects with HIV infection, 8 subjects had a CD4 $+\leq 200$ cell count $(13.3 \%)$ and 10 subjects had a CD4 $>200$ cell count (16.7\%). Table 3 illustrates the case of anogenital condyloma acuminata with CD4 $+\leq 200$ cell counts having genital condyloma acuminata severity with a value of 4 in 1 person $(5.5 \%)$ and a value of 5 in 1 person (5.5\%). The case of anogenital condyloma acuminata with CD4 $+\leq 200$ cell counts having perianal condyloma acuminata severity with a value of 4 in 1 person (5.5\%) and a value of 5 in 2 people $(11.1 \%)$ and the case of anogenital condyloma acuminata with CD4 $+\leq 200$ cell count having intraanal condyloma acuminata with a value of 4 in 2 people $(11.1 \%)$ and a value of 5 in 4 people $(22.2 \%)$ (Table 3$)$.

The mean plasma zinc level in subjects with condyloma acuminata with HIV infection was found to be $57.27 \pm 8.32$ $\mu \mathrm{g} / \mathrm{dL}$, whereas in subjects with condyloma acuminata without HIV infection the plasma zinc level was found to be $64.59 \pm 8.20 \mu \mathrm{g} / \mathrm{dL}$. The mean plasma zinc level was found to be lower in subjects with condyloma acuminata with HIV infection than condyloma acuminata without HIV infection with an average difference of 7.31 (95\% CI 2.25 - 12.37). The results of the unpaired $\mathrm{T}$ test showed 
Table 1. Sociodemographic Characteristics of Condyloma Acuminata in term of HIV Infection

\begin{tabular}{|c|c|c|c|}
\hline Characteristic & $\begin{array}{c}\text { Condyloma Acuminata without } \\
\text { HIVn }=27(\%)\end{array}$ & $\begin{array}{l}\text { Condyloma Acuminata with HIV } \\
n=18(\%)\end{array}$ & p-value \\
\hline Age & & & 0.346 \\
\hline $15-19$ years & $1(1.7)$ & $1(1.7)$ & \\
\hline $20-24$ years & $8(13.3)$ & $2(3.3)$ & \\
\hline $25-29$ years & $6(10.0)$ & $7(11.7)$ & \\
\hline $30-34$ years & $5(8.3)$ & $1(1.7)$ & \\
\hline $35-39$ years & $2(3.3)$ & $2(3.3)$ & \\
\hline $40-44$ years & $2(3.3)$ & $0(0)$ & \\
\hline $45-49$ years & $3(5.0)$ & $2(3.3)$ & \\
\hline $50-54$ years & $0(0)$ & $0(0)$ & \\
\hline $55-60$ years & $0(0)$ & $1(1.7)$ & \\
\hline Sex & & & $<0.05$ \\
\hline Male & $12(20)$ & $16(26.7)$ & \\
\hline Female & $15(25)$ & $2(3.3)$ & \\
\hline Sexual Orientation & & & $<0.05$ \\
\hline Homosexual & $4(6.7)$ & $15(25)$ & \\
\hline Heterosexual & $23(38.3)$ & $2(3.3)$ & \\
\hline Bisexual & $0(0)$ & $1(1.7)$ & \\
\hline First sexual contact & & & 0.893 \\
\hline$<17$ years & $20(33.3)$ & $13(21.7)$ & \\
\hline$\geq 17$ years & $7(11.7)$ & $5(8.3)$ & \\
\hline Location of lesion & & & $<0.05$ \\
\hline Genital & $24(40)$ & $2(3.3)$ & \\
\hline Intra-anal mucosa & $1(1.7)$ & $8(13.3)$ & \\
\hline Perianal & $1(1.7)$ & $3(5.0)$ & \\
\hline Intra-anal and perianal mucosa & $1(1.7)$ & $3(5.0)$ & \\
\hline Genital and perianal & $0(0)$ & $2(3.3)$ & \\
\hline Clinical form of lesion & & & 0.501 \\
\hline Acuminata & $12(20)$ & $8(13.3)$ & \\
\hline Keratotic papules & $10(16.7)$ & $8(13.3)$ & \\
\hline Flat surfaced papules & $3(5)$ & $0(0)$ & \\
\hline Giant Kondiloma Acuminata & $2(3.3)$ & $2(3.3)$ & \\
\hline \multicolumn{4}{|l|}{ Case Type } \\
\hline New case & $17(28.3)$ & $9(15)$ & \\
\hline Recurring Case & $10(16.7)$ & $9(15)$ & 0.388 \\
\hline \multicolumn{4}{|l|}{ Duration of condyloma acuminata } \\
\hline$<1$ year & $20(33.3)$ & $16(26.7)$ & 0.464 \\
\hline$>1$ year & $7(11.7)$ & $2(3.3)$ & \\
\hline \multicolumn{4}{|l|}{ Attendant complaint } \\
\hline Itch & $10(16.7)$ & $5(8.3)$ & \\
\hline Pain & $1(1.7)$ & $0(0)$ & \\
\hline No complaints & $16(26.7)$ & $13(21.7)$ & 0.306 \\
\hline Treatment history & & & 0.072 \\
\hline Spotted TCA $80 \%$ & $14(23.3)$ & $15(25)$ & \\
\hline Podophylline sprains with $25 \%$ & $8(13.3)$ & $3(5)$ & \\
\hline Electric surgery & $5(8.3)$ & $0(0)$ & \\
\hline
\end{tabular}

that the average plasma zinc in condyloma acuminata subjects with HIV infection was lower compared to those with condyloma acuminata without HIV infection with a p value of $<0.05$ (Table 4) 
Table 2. Value of Genital, Perianal, and Intravenous Condyloma Acuminata Severity in Terms of HIV Infection

\begin{tabular}{|c|c|c|}
\hline Characteristic & $\begin{array}{c}\text { Condyloma } \\
\text { Acuminata without HIV } \\
\mathrm{n}=27(\%)\end{array}$ & $\begin{array}{c}\text { Condyloma } \\
\text { Acuminata with HIV } \\
\mathrm{n}=18(\%)\end{array}$ \\
\hline \multicolumn{3}{|l|}{ The severity of condyloma acuminata in the genitalia } \\
\hline 1. (Number of lesions $1-3$, size $1-4 \mathrm{~mm}$ ) & $4(6.7)$ & $1(1.7)$ \\
\hline 2. (Number of lesions $>3$, size $1-4 \mathrm{~mm}$, covering $5 \%-30 \%$ of the genital area) & $9(15)$ & $0(0)$ \\
\hline 3. (Confluent lesions covering $30 \%-50 \%$ of the genital area) & $2(3.3)$ & $1(1.7)$ \\
\hline 4. (Confluent lesions covering $50 \%-75 \%$ of the genital area) & $5(8.3)$ & $1(1.7)$ \\
\hline 5. (Confluent lesions covering $>75 \%$ of the genital area) & $5(8.3)$ & $1(1.7)$ \\
\hline \multicolumn{3}{|l|}{ The severity of condyloma acuminata in perianal } \\
\hline 1. (Number of lesions $1-3$, size $1-4 \mathrm{~mm}$ ) & $0(0)$ & $0(0)$ \\
\hline 2. (Number of lesions $>3$, size $1-4 \mathrm{~mm}$, covering $5 \%-30 \%$ perianal area) & $0(0)$ & $3(5)$ \\
\hline 3. (Confluent lesions covering $30 \%-50 \%$ perianal area) & $2(3.3)$ & $1(1.7)$ \\
\hline 4. (Conflict lesions covering $50 \%$ - 75\% perianal area) & $0(0)$ & $2(3.3)$ \\
\hline 5. (Confluent lesions covering $>75 \%$ perianal area) & $0(0)$ & $2(3.3)$ \\
\hline \multicolumn{3}{|l|}{ The severity of condyloma acuminata intraanal } \\
\hline 1. (Number of lesions $1-3$, size $1-4 \mathrm{~mm}$ ) & $0(0)$ & $0(0)$ \\
\hline 2. (Number of lesions $>3$, size $1-4 \mathrm{~mm}$, covering $5 \%-30 \%$ of the intravenous area) & $0(0)$ & $1(1.7)$ \\
\hline 3. (Confluent lesions covering $30 \%-50 \%$ of the intravenous area) & $0(0)$ & $3(5)$ \\
\hline 4. (Confluent lesions covering $50 \%-75 \%$ of the intravenous area) & $1(1.7)$ & $3(5)$ \\
\hline 5. (Confluent lesions covering $>75 \%$ of the intravenous area) & $0(0)$ & $4(6,7)$ \\
\hline
\end{tabular}

\section{Discussion}

Current findings based on sexual orientation, 23 subjects $(38.3 \%)$ were heterosexual while the majority of condyloma acuminata subjects with 15 HIV infections $(25 \%)$ were homosexual. The sexual orientation in condyloma acuminata subjects also determines the location of the condyloma acuminata lesion. In the condyloma acuminata subject group without HIV infection most condyloma acuminata lesions were found in the genitalia in 24 subjects $(40 \%)$, whereas in the subject group of condyloma acuminata with HIV infection most condyloma acuminata lesions were found in the intraanal mucosa in 8 subjects (13.3\%). In the anal mucosa there is a transition zone above the dentate line, which transition from squamous epithelial cells to columnar epithelial cells. Epithelial cells found in the transition zone are immature epithelial cells so that microtrauma and HPV can easily reach basal cells during anal intercourse (Habibie et al., 2016; Ogawa et al., 2016; Lee et al., 2011;

Table 3. Characteristics of CD4 + Cell Counts Against the Severity of Condyloma Acuminata in the Genitalia, Perianal, and Intraanal

\begin{tabular}{|c|c|c|c|c|c|}
\hline \multirow[t]{2}{*}{ CD4+ Cell count } & \multicolumn{5}{|c|}{ Severity of Condiloma Acuminata in Genital $n=18(40 \%)$} \\
\hline & 1 & 2 & 3 & 4 & 5 \\
\hline$\leq 200$ & $0(0.0)$ & $0(0.0)$ & $0(0.0)$ & $1(5.5)$ & $1(5.5)$ \\
\hline \multirow[t]{2}{*}{$>200$} & $1(5.5)$ & 0 & $1(5.5)$ & $0(0.0)$ & $0(0.0)$ \\
\hline & \multicolumn{5}{|c|}{ Severity of Kondiloma Acuminata in Perianal $n=18(40 \%)$} \\
\hline$\leq 200$ & $0(0.0)$ & $0(0.0)$ & $1(5.5)$ & $1(5.5)$ & $2(11.1)$ \\
\hline \multirow[t]{2}{*}{$>200$} & $0(0.0)$ & $3(16.6)$ & $0(0.0)$ & $1(5.5)$ & $0(0.0)$ \\
\hline & \multicolumn{5}{|c|}{ Degree of Severity of Kondiloma Acuminata in Intraanal $n=18(40 \%)$} \\
\hline$\leq 200$ & $0(0.0)$ & $0(0.0)$ & $0(0.0)$ & $2(11.1)$ & $4(22.2)$ \\
\hline$>200$ & $0(0.0)$ & $1(5.5)$ & $3(16.6)$ & $1(5.5)$ & $0(0.0)$ \\
\hline
\end{tabular}

Table 4. Differences in Mean Plasma Zinc Levels in Subjects with Condyloma Acuminata with and without HIV Infection

\begin{tabular}{llcc}
\hline Group & $\mathrm{N}$ & Average Zinc Plasma Level (Mean \pm SD) $(\mu \mathrm{g} / \mathrm{dL})$ & $\mathrm{p}$-value \\
\hline Condyloma acuminata with HIV infection & 18 & $57.27 \pm 8.32$ & 0.006 \\
Condyloma acuminata without HIV infection & 27 & $64.59 \pm 8.20$ & \\
\hline
\end{tabular}


Sousa et al., 2012).

The clinical form of anogenital condyloma acuminata lesions in subjects without HIV infection was mostly acuminata as many as 12 people $(20 \%)$, whereas in subjects with condyloma acuminata without HIV infection most were clinical forms of acuminata and keratotic papules, each of which was 8 people $(18,3 \%)$. The study by Aynaud et al., (1998) found that the morphology of condyloma acuminata lesions in patients with HIV infection was the same as patients without HIV infection. Most condyloma acuminata lesions are exophilic, found in $85.1 \%$ of patients with HIV and $84.2 \%$ of patients without HIV.

The cases of anogenital condyloma acuminata that occur in subjects with anogenital condyloma acuminata without HIV infection are mostly new cases, as many as 17 people $(28.3 \%)$, whereas anogenital condyloma acuminata cases that occur in anogenital condyloma acuminata subjects with HIV infection have the same number in new cases and recurrence of 9 people $(15 \%)$ respectively. When an acute HPV infection heals without clinical symptoms, it will enter a latent period because the non-producing virus is removed by the body so that it can continue to focus on viral replication (Lee et al., 2011). Under conditions of decreased cellular immunity such as with HIV will increase the recurrence of condyloma acuminata. Study by Sung et al., (2012) show that the average recurrence time of anal condyloma acuminata lesions in HIV patients was 5.1 months with a range of 1.3 months to 14.2 months. Decreased plasma zinc levels also affected recurrence of anogenital condyloma acuminata due to a decrease in cellular immunity. In this study most cases of recurrent condyloma acuminata, as many as 18 subjects (40\%) had low plasma zinc levels $(<67.5 \mu \mathrm{g} / \mathrm{dL})$ and only 1 subject $(2,2 \%)$ in the case of recurrent condyloma acuminata having normal plasma zinc levels.

The duration of anogenital condyloma acuminata that occurs in subjects with anogenital condyloma acuminata with HIV infection is mostly less than 1 year as many as 16 people $(26.7 \%)$, whereas in anogenital condyloma acuminata subjects without HIV infection most of them are less than 1 year as many as 20 people (33.3\%). In a study conducted by Ramanakumar et al., (2016) the median duration of infection was also influenced by type of HPV, median duration was found to be longer in high-risk HPV (HPV type 16 with media infection duration 11.8 months) compared with low risk HPV (HPV type 6 with a median infection duration of 6.5 months). In subjects with HIV infection the duration of experiencing condyloma acuminata should be longer with a duration of more than 1 year due to a decrease in cellular immunity which results in high viral activity. The prevalence and persistence of HPV infection increases with the degree of immunodeficiency and progression of HIV disease (Moscikci et al., 2004; Fontaine et al., 2008; Orkin, 2001).

The study by Lu et al., (2012) found an association between a decrease in CD4 + cell count and an increase in HIV load in HIV patients with the largest size of condyloma acuminata lesions based on length times width $\left(\mathrm{mm}^{2}\right)$. Low (2011) reported that HIV-seropositive women with CD4 $+<200$ cell counts were 20 times more likely to suffer from condyloma acuminata than women without HIV infection. Whereas HIV-seropositive women with CD4 + counts $>200$ have a risk of suffering from condyloma acuminata 6 times greater than HIV-uninfected women. Although in this study, the subjects were more of anogenital condyloma acuminates who had CD4 + cell counts $>200$, cases of anogenital condyloma acuminata with CD4 $+\leq 200$ cell counts experienced more severe genital, perianal and intraanal condyloma acuminata than those with CD4 + counts $>200$. Subjects with CD4 + 200 cells with a genital severity value of 5 was found in 1 people $(5.5 \%), \mathrm{CD} 4+\leq 200$ cell count with a perianal severity value of 5 was found in 2 people $(11.1 \%)$, CD $4+$ $\leq 200$ cell count a perianal severity value of 5 was found in 4 people $(22.2 \%)$.

The incidence of condyloma acuminata in subjects with HIV infection, besides being influenced by CD4 + levels, was also influenced by the treatment history of the condyloma lesion and a history of receiving ARV treatment. In this study the most frequent history of treatment given to subjects with condyloma acuminata with HIV infection was $80 \%$ TCA, as many as 15 people $(25 \%)$. This therapy was repeated once every week dan subsequently repeated if the lesion persist. For condyloma acuminata that is smaller size and few in numbers, therapy can be done up to 6 times. When ever the size is too huge and persist after 6 course of therapy, different types of modalities can be considered (Lee et al., 2016; Fathi et al., 2014).

In this study the mean plasma zinc level was found to be lower in subjects with condyloma acuminata with HIV infection than condyloma acuminata without HIV infection. Previous studies comparing plasma zinc levels in subjects with condyloma acuminata with HIV infection and subjects with condyloma acuminata without HIV infection have never been done. Research conducted by Mandueke et al., (2015) comparing plasma zinc levels in subjects with HIV infection and without HIV infection found that the average plasma zinc level in subjects with HIV infection $(88.35 \pm 5.49)$ was lower compared to subjects without HIV infection $(122.62 \pm 8.57)$ with a value of $\mathrm{p}<0.001$.

Previous research also found that plasma zinc levels were found to be low in subjects with HIV infection. Research conducted by Baum (2003) found that in subjects with HIV infection as many as $56 \%$ of subjects experienced zinc deficiency (plasma zinc level $<75 \mu \mathrm{g} /$ dL). The study conducted by Koch et al., (1996) stated that as many as $228 \mathrm{HIV}$-infected adults as many as 51\% experienced plasma zinc deficiency (plasma zinc level $\leq$ $65 \mu \mathrm{g} / \mathrm{dL})$.

Factors that can affect the mean lower plasma zinc level in subjects with HIV infection are gastrointestinal disorders experienced by subjects with HIV infection such as decreased appetite and nausea and vomiting, hence the foods containing zinc intake decreases (Sibbery et al., 2002). Research conducted by Baum et al., (2003) showed that there is a relationship between low plasma zinc levels and decreased CD4 + cell count. This zinc deficiency condition is usually found in HIV infection subjects with CD4 $+<200$ cell counts with OR 1.72 and $\mathrm{p}=0.002$. In 
this study, low plasma zinc levels (less than $67.5 \mu \mathrm{g} / \mathrm{dL}$ ) was found in 8 anogenital condyloma acuminata subjects in HIV infection with CD4 $+\leq 200$ cell counts.

Zinc is an indispensable element in the formation of tiamulin hormones therefore zinc deficiency conditions can cause thymic atrophy and a reduction in the number of timocytes (Blewett et al., 2012). Thymus has a very important role for $\mathrm{T}$ cell maturation; a decrease in the maturation of Th1 cells will reduce IL-2 production and INF- $\gamma$. A decrease in IL-2 will decrease NK cells and cytotoxic activity of T cells. The production of IL-2 and INF- $\gamma$ by macrophages and monocytes also decreases in the event of zinc deficiency (Prasad, 2009). This reduction in immune response from hosts due to zinc deficiency will affect the ability to inhibit reproduction of the HPV virus.

Zinc deficiency will also affect apoptosis of HPV-infected cells. The disruption of apoptotic regulation plays an important role in the pathogenesis of HPV infection (Li et al., 2005). Protein E6 and E7 plays an important role in the pathogenesis of persistent HPV infection. Protein E6 and E7 can inhibit tumor suppressor genes (p53 and pRB) on host cells, so that HPV can continue to experience replication and transcription to maintain the viral genome (Shanmugasundaram et al., 2017). Research conducted by Bae et al., (2017) shows that intracellular zinc accumulation will inhibit E6 protein and E7. This shows that zinc decreases Bcl-2 expression and also increases p53 expression or activates caspase-3. Bax is a proapoptotic protein that increases cell death, the mechanism of action of Bax is in contrast to Bcl-2.

Zinc can also inhibit the formation of Reactive Oxygen Species (ROS), if the ROS is inhibited, then NF- $\mathrm{kB}$ activation will not occur further, so it will inhibit the activation of the growth factor (VEGF, cyclin D1, EGFR) and anti-apoptotic molecules (Bcl2, BclXL, cIAP- 2). Zinc deficiency can result in reduced barriers to ROS, which will increase NF- $\mathrm{KB}$ activation then will increase activation of growth factor formation (VEGF, cyclin D1, EGFR) and anti-apoptotic molecules (Bcl2, BclXL, cIAP-2) (Prasad, 2009).

The limitation in this study is the absence of a predictive model that is able to describe the correlation between serum zinc and the severity of condyloma acuminata, and there has not been a causal analysis model for the role of zinc in recurrence of condyloma acuminata in patient with coinfection of HIV.

Recommendations that can be given to condyloma patients with HIV coinfection based on the results of this finding are zinc supplementation to provide modulation of the immune system and enhance regulation of cell apoptosis.

In conclusion the mean plasma zinc level in subjects with condyloma acuminata with HIV infection was significantly lower than without HIV infection. Zinc supplementation can be recommended in patients with condyloma akuminata which is accompanied by HIV infection.

\section{Ethical Aspect}

All participant in this study has signed an inform consent regarding the research procedure and publication of the article. This study has been aprroved by ethical committee of Sanglah General Hospital-Faculty of Medicine Udayana University with references number 1365/UN14.2.2/PD/KEP/2018.

\section{Funding}

This research doesn't receive any spesific grant from government or any private sector.

\section{Conflict of interest}

The author declare there is no conflict of interest regarding all element on this study

\section{Acknowledgements}

The author acknowledge all of dermatology and venereology attending resident for the assistance in collecting samples also to all clinical pathology laboratory staff for sample zinc analysis.

\section{References}

Aynaud F, Piron D, Barraso R, et al (1998). Comparison of clinical, histological, and virological symptoms of HPV in HIV-1 infected men and immunocompetent subjects. Sex Transm Inf, 74, 32-4.

Bae SY, Lee KH, Kim JW, et al (2017). Zinc induces apoptosis on cervical carcinoma cells by $\mathrm{p}-53$ dependent and independent pathway. Biochem Biophys Res Commun, 441, 218-23.

Baum MK, Campa A, Lai S, et al (2003). Zinc status in human immunodeficiency virus type 1 infections and illicit drug use. Clin Infect Dis, 37, 117-23.

Blewett HJ, Taylor CG (2012). Dietary Zinc dificiency in rodents: Effect on T-Cell development, maturation, and phenotype. Nutrient, 4, 449-66.

Burk RD, Chen Z, Harari A, et al (2011). Clasification and nomenclature system for human alpha papillomavirus variants: General Feature, Nucleotide Landmarks and Assigment of HPV 6 and HPV 11 Isolates to Variants Lineages. Acta Dermatovenerol Alp Panonica Adriat, 20, 113-23.

Chaturvedi AK, Madeleine MM, Biggar RJ, et al (2009). Risk of human papillomavirus - associated cancers among persons with AIDS. J Natl Cancer Inst, 101, 1120-30.

Fathi R, Tsoukas MM (2014). Genital warts and other HPV infections: Established and novel therapies. Clin Dermatol, 32, 299-306.

Fontaine J, Hankins C, Money D, et al (2008). Human papillomavirus type 16 (HPV-16) viral load and persistence of HPV-16 infection in women infected or at risk for HIV. J Clin Virol, 43, 307-12.

Gerberding JL (2004). Prevention of genital human papillomavirus infection: Report to Congress. Atlanta, GA: Center for Disease Control and Prevention. Department of Health and Human Services, 3.

Habibie DP, Barakbah J (2016). Retrospective study: condyloma acuminata profile in HIV/AIDS patient. Anna Indonesian Dermatol Venereol, 28, 1-7.

Kobayashi A, Greenblatt RM, Anastos K, et al (2008). Functional atrributes of mucosal immunity in cervical intraepithelial neoplasia and effect of HIV infection. Cancer Res, 64, 6766-74.

Koch J, Neal E, Schlott M, et al (1996). Zinc level and infections in hospitalized patients with AIDS. Nutrition, 12, 515-8.

Lee BC, Choe HS, Lee SJ, et al (2011). Epidemiological 
characteristics of genital herpes and condyloma acuminata in patients presenting to urologic and gynecologic clinics in Korea. J Infect Chem, 17, 351-7.

Lee JT, Goldberg SM, Madoff RD, et al (2016). Immune status does not predict high-risk HPV in anal condyloma. J Surg Res, 8, 166-9.

Levi G, Feldman J, Holman S, et al (2005). Relationship between HIV Viral load and Langerhans cellls of the cervical epithelium. J Obstet Gynaecol Res, 31, 178-84.

Li TT, Quan SM, Yang BK, et al (2005). Regulation of apoptosis by the papillomavirus E6 oncogenes. World J Gastroenterol, 11, 931-7.

Low AJ, Clayton T, Konate I, et al (2011). Genital warts and infection with human immunodeficiency virus in high risk women in Burkina Faso: A Longitudinal Study. BMC Infect Dis, 11, 1-9.

Lu HN, Amirian ES, Chan W, et al (2012). CD4+ cell count and HIV load as predictors of anal warts over time in HIVinfected women. J Infect Dis, 2, 1-8.

Madueke NM, Osaronowen EM, Samuel OO, et al (2015). Comparative study of plasma Zinc and Selenium levels among Human Immunodeficiency Virus (HIV) positive and negative subjects. Afr J Food Sci Technol, 6, 253-8.

Moscikci AB, Ellenberg JH, Farhat S, et al (2004). Persistence of Human Papillomavirus infection in HIV-infected and-uninfected adolescent girls: Risk factors and differences by phylogenic type. $J$ Infect Dis, 190, 37-45.

Ogawa Y, Kawamura T, Shimada S, et al (2016). Zinc and skin biology. Arch Biochem Biophys, 611, 113-9.

Orkin BA (2001). Operative management of anal and perianal complication of HIV infection and condyloma. Oper Tech General Surg, 3, 165-70.

Palefsky JM, Rubin M, Karkovich M, et al (2009). The epidemiology of anal Human Papillomavirus and related neoplasia. Obstet Gynecol Clin North Am, 36, 187-200.

Prasad AS (2009). Zinc: Role in immunity, oxidative stress, and chronic inflammation. Curr Opin Clin Nutr Metab Care, 12, 646-52.

Puspawati N, Sissy S, Gotama D, et al (2018). A retrospective study of condyloma acuminata profile in outpatient clinic of dermato-venereology Sanglah General Hospital Denpasar, Bali-Indonesia period 2015-2017. Bali Dermatol Venereol J, 1, 1-3.

Ramanakumar AV, Karyasa SD, Kenneth M, et al (2016). Incidence and duration of type-specific Human Papillomavirus infection in high-risk HPV-naive women: Result from the control arm of phase II HPV-16/18 vaccine trial. $B M J, \mathbf{6}, 1-10$.

Shanmugasundaram S, You J (2017). Review targeting persistent Human Papilloma virus infection. Viruses, 229, 1-14.

Siberry GK, Ruff AJ, Black R, et al (2002). Zinc and human immunodeficiency virus infection. Nutr Res, 22, 527-38.

Sousa JB, Duraes LCD, Kimmy J, et al (2012). Human Papilloma virus and anal cancer. In: Malla Nancy, editor. Sexually Transmitted Infection. 1st Ed. Europe: In Tech Europe. pp $141-54$.

Sung JH, Ahn EJ, Oh HK, et al (2012). Association of immune status with recurrent anal condylomata in human immunodeficiency virus-positive patients. J Korean Sos Coloproctol, 28, 294-8.

\section{(ब) $(\mathbb{\theta}$}

This work is licensed under a Creative Commons AttributionNon Commercial 4.0 International License. 